usefully be transferred to institutions for them to spend instead. By making deals with individual students about repayment in kind for financial help, to which end they would have an incentive for the first time, much better use would be made of the resources spent on student aid and more students would be helped. So why not give that a try?

But no more than half of what the government spends should be administered by the universities, polytechnics and colleges, for too much power over the fates of students would give them the illusion that their individual sizes had been fixed for good. That is why the greater part of present government aid for students should be spent quite differently, on individual student scholarships that individual students may take to the institutions of their choice. Together, these two components of a different system could contain the present cost of student aid, make more efficient use of what is spent, restore a measure of autonomy to higher educational institutions which have already lost too much of it and restore a sense of independence to students, who cannot wholly welcome the idea of beginning adult life as clients of a creaking system of social benefits.

There are several snags, not the least of which is the government's own predilection towards the notion that business, which benefits from such skill as British higher education engenders, should step in to help, by means of sponsorship schemes for potential employees. This was the general cry when Baker announced his new inquiry in the House of Commons last week. But a scheme that puts students in the pockets of future employers is no better than one that makes them depend on social security. So why not student loans? The Prime Minister's promise that grants would be replaced by loans has twice been defeated by the Treasury's calculation that the short-term cost would be increased, but that objection applies only if the whole of student aid at present is shifted to the banks. There is, however, a need for assistance at the margin by way of loans for students whose opinions of the benefits of higher education to themselves may differ from those of the authorities, as well as for those who seek a second change or a period of retraining. Why should not Britain follow a dozen other countries by making a modest beginning with loans for people in such special circumstances?

\section{Selling lamb short}

\section{The British government's decision to ban the sale of some lambs may yet backfire.}

THE British Ministry of Agriculture, Fisheries and Food seems to have had a bad Chernobyl. In the days immediately after the tragic accident in the Ukraine, there was a general complaint that too little had been done too late to monitor the occurrence of radionuclides in British food. Matters were not much helped by the appearance of the Secretary of State, Mr Michael Jopling, on a television programme in the course of which it became clear that he had not previously heard of the notion that doses of radiation smaller than the accepted safety limits could nevertheless be dangerous. Now the ministry has swung from complacency to the other extreme, and has banned for 21 days from last Friday the sale of lamb from North Wales and Cumbria. The decision seems to have been taken on the strength of 100 measurements of ${ }^{1: 7} \mathrm{Cs}$ in lambs born earlier this season, 19 of which showed more than $600 \mathrm{~Bq} \mathrm{~kg}^{-1}$ of total caesium among which were 9 exceeding $1,000 \mathrm{~Bq} \mathrm{~kg}^{-1}$. The ministry, not now particularly popular among hill farmers for its expressed (and reasonable) wish to reduce the subsidies it pays them, will find that its wish to be seen to be active about fallout from Chernobyl will lose one of the few markets on which its dependent farmers rely.

The circumstances are curious. The ministry is "erring on the side of caution", as one of its spokesmen said this week, to a degree that may prove economically unwise. Although caesium is one of the predominant radioactive components of fission products, it differs from iodine, strontium and plutonium in being a generalized constitutent of the mammalian torso. The result is that, although the radioactive half-life of ${ }^{137} \mathrm{Cs}$ is roughly 30 years, the residence of the material in people and sheep is much less, more like 30 days than 30 years. The highest concentrations of ${ }^{134.137} \mathrm{Cs}$ have been found in British sheep where rainfall was heaviest early in May (which is where the agriculture ministry looked for them), and in lambs rather than older animals, a factor to some extent offset by the fact that the biological half-life is even less in lambs than in sheep, perhaps as little as 15 days. Yet the ministry has banned the sale of lambs from Britain's soggiest sheep-farms on the strength of observations of levels of contamination in a proportion of the animals sampled which is much less than the $9,000 \mathrm{~Bq} \mathrm{~kg}^{-1}$ defined as the Emergency Reference Level by the National Radiological Protection Board, an independent public agency. Why the fuss?

Not only domestic politics is involved. Soon after the accident at Chernobyl, the European Commission was stampeded by some of its member governments into an undiscriminating ban on the import of foodstuffs from Eastern Europe. For regulatory purposes, the permissible limit on the radioactive content of food was fixed at $600 \mathrm{~Bq} \mathrm{~kg}^{-1}$, partly on the grounds that nobody at the outset knew the composition of the fallout, which might have contained more plutonium than appears to have been the case. Now, after the event, the European Commission seems to have been doing its best to justify its decision. A meeting of experts called under the aegis of the Euratom Treaty has apparently recommended that the "action level" for the radioactive content of foodstuffs should be $1,000 \mathrm{~Bq} \mathrm{~kg}^{-1}$, a factor of nearly ten below that recommended by the radiological protection board. The British ministry seems to have acted on lamb because this limit has been exceeded in some of the animals slaughtered in the past week or so.

Nobody will weep too much for the farmers whose trade will be affected, but the general scare about lamb will have more lasting consequences. It seems to be agreed that the annual dose of radiation arising from an average diet of lamb uniformly contaminated to the $1,000 \mathrm{~Bq}$ level would be $0.15 \mathrm{mSv}$, an estimate already biased on the side of caution because the calculation is based on the physiology of a 10 -year-old child. This is a small fraction of the annual dose in Britain due to natural radiation, estimated at $2 \mathrm{mSv}$, and less even than the fluctuation of the natural dose from one part of the country to another. The International Commission on Radiological Protection allows that artificial doses for members of the general population should not exceed $5 \mathrm{mSv}$ in any year, or more than 2 $\mathrm{mSv}$ a year chronically. But to acquire even $0.15 \mathrm{mSv}$ a year from this season's British lamb, people would have to start with heavily contaminated lambs, keep them in a freezer and eat nothing else. The agriculture ministry may have done something to protect a few lamb-gluttons from the small risks of their excesses, and at the same time to suggest that it is an action ministry, but the general effect of its hasty decision will be unwelcome.

The particular danger in the ministry's over-active response is that it will reinforce the general opinion that radiation and radioactivity are mysterious and awesome entities. If it should be necessary to ban British lamb from sale several weeks after the passage of a radioactive cloud, who can hope to be safe from it? The truth, of course, is that calculations of the kind on which the ministry based its decision are by no means uncertain. The notion that caesuim, radioactive or otherwise. travels through soil into grass and from there into the bodies of grazing animals in a relatively slow fashion is well described. The calculation of the radiation doses that result are intricate but relatively precise. The fact that the doses likely to be received by British lamb-fanciers are so much smaller than the internationally agreed limits and the natural background should help people to live with the knowledge that the damage done by radiation is less certainly calculated. Haste will have the opposite effect. 